\title{
Sex Hormone-Binding Globulin in Children and Adolescents
}

\author{
Banu Aydın, Stephen J. Winters \\ University of Louisville Faculty of Medicine, Division of Endocrinology, Metabolism and Diabetes, Kentucky, USA
}

\section{ABSTRACT}

Sex hormone-binding globulin (SHBG) is a circulating glycoprotein that transports testosterone and other steroids in the blood. Interest in SHBG has escalated in recent years because of its inverse association with obesity and insulin resistance, and because many studies have linked lower circulating levels of SHBG to metabolic syndrome, type 2 diabetes, nonalcoholic fatty liver disease, polycystic ovary syndrome, and early puberty. The purpose of this review is to summarize molecular, clinical, endocrine, and epidemiological findings to illustrate how measurement of plasma SHBG may be useful in clinical medicine in children.

Keywords: Sex hormone-binding globulin, obesity, type 2 diabetes, metabolic syndrome, non-alcoholic fatty liver disease, polycystic ovary syndrome

Conflict of interest: None declared

Received: 23.12 .2015

Accepted: 06.01.2016

\section{WHAT IS ALREADY KNOWN ON THIS TOPIC?}

Sex hormone-binding globulin (SHBG) is a glycoprotein produced in the liver that transports certain sex steroids in the circulation and regulates their access to target cells. Many studies have linked lower circulating levels of SHBG to obesity, type 2 diabetes, metabolic syndrome, non-alcoholic fatty liver disease, polycystic ovary syndrome, and early puberty.

\section{WHAT THIS STUDY ADDS?}

Our review was written to summarize the molecular, clinical, endocrine, and epidemiological findings which illustrate how measurement of plasma SHBG levels may be useful in clinical medicine in children. We believe that this review is novel and will be useful for the physicians who manage pediatric obesity and related comorbidities and for scientists who conduct translational research in this area.

\section{Introduction}

Sex hormone-binding globulin (SHBG) is a 90-100 KDa homodimeric glycoprotein that is encoded by a single gene on the short arm of chromosome 17. Variable glycosylation explains the variation in molecular weight and is known to be increased by estrogens, but its significance is unknown. Circulating SHBG is produced primarily by hepatocytes, however, the gene is also expressed in the brain, uterus, prostate, breast, ovary, and testis (1), as well as in certain ovarian and prostate cancers. SHBG is found in the circulation of numerous mammals but is seemingly absent in the plasma of adult rats and mice, guinea pigs, and pigs. SHBG transports testosterone and other steroids in the blood plasma, reduces their metabolic clearance rate, and regulates their access to target tissues (2). While SHBG can sequester steroids from target tissues, there is some evidence that ligandbound SHBG binds to membrane receptors, and stimulates cyclic 
adenosine monophosphate production (3), and/or enters cells by binding to the membrane protein megalin (4) to initiate a biological effect. Human SHBG binds dihydrotestosterone $(\mathrm{DHT})>$ testosterone $>$ estradiol as well as drugs such as levonorgestrel and fluoxymesterone (2).

Homozygous missense mutation resulting in a complete deficiency of plasma SHBG has been reported in a few cases. An affected adult male complained of low libido, decreased spontaneous morning erections, fatigue, muscular weakness, decreased shaving frequency, and had small testes and a low bone mass. His semen analysis was normal, however. His affected sister had delayed menarche, small breasts, and irregular menstrual periods (3). An adult woman with an undetectable level of SHBG and a compound heterozygote polymorphism had mild hirsutism that increased dramatically during a pregnancy when her free testosterone level was 4-fold elevated (4) suggesting that SHBG functions to protect the pregnant woman from placental hyperandrogenism. Polymorphisms have been reported that more subtly affect SHBG binding of testosterone.

SHBG binds testosterone with high affinity ( 1 nmol/L) and much of the SHBG-binding sites in adult male serum are occupied by testosterone such that the level of SHBG is a major determinant of the total testosterone level in adult men. Eugonadal adult men with low SHBG levels have low total testosterone levels, while men with high SHBG levels have higher testosterone levels. Obesity and hyperthyroidism, respectively, are examples of these effects. SHBG and testosterone are also related in newborn boys (5) during minipuberty but not in prepubertal boys with much lower testosterone levels in whom only a small portion of the SHBG in the plasma is occupied by testosterone (Figure 1).

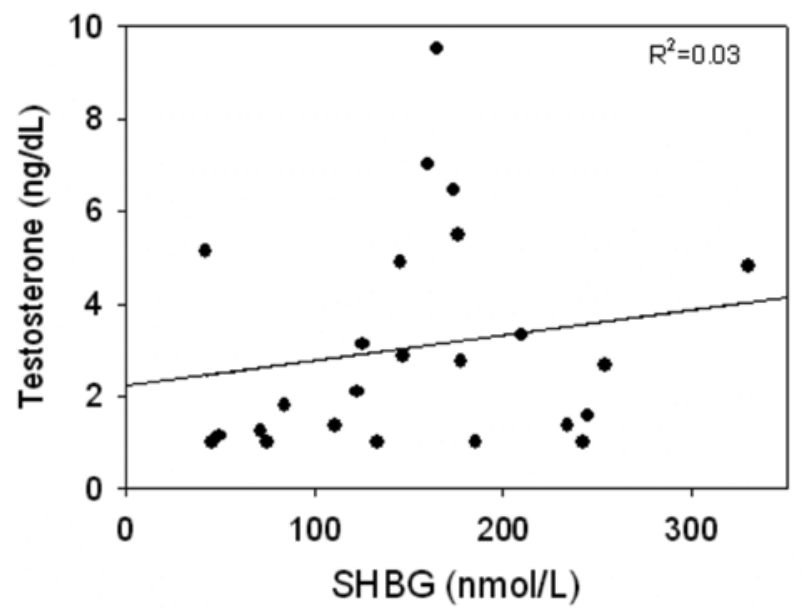

Figure 1. Relationship between sex hormone-binding globulin and total testosterone levels in prepubertal boys age 5-8 years, data from reference (82). SHBG: sex hormone-binding globulin

\section{Sex Hormone-Binding Globulin in Children and Adolescents}

SHBG is present in the fetal circulation and in cord blood where levels are similar in males and females (6). SHBG levels are markedly increased in the maternal circulation due to the effect of placental estrogens, whereas the levels in cord blood are low and similar to values on day 2 of life. Whether SHBG plays a physiological role during fetal life is unknown. In one study of women from China, cord blood SHBG levels were lower among babies born to overweight mothers, most of whom had gestational diabetes (7).

As diagrammed in Figure 2, some cross-sectional studies indicate that SHBG levels rise substantially from birth to early childhood (8), whereas other studies indicate unchanged values (9). Longitudinal studies are lacking. During childhood, values are relatively stable but then decline at puberty, more so in boys than in girls (10). The reason for this change is not certain, but it is probably partly from androgens which are known to suppress SHBG levels (11). However, the decline is also seen in boys with idiopathic hypopituitarism (12) suggesting metabolic rather than neuroendocrine control. SHBG levels in adulthood are higher in women than in men, which is probably due to estradiol since estrogen administration is known to increase SHBG (13). Levels then rise slightly in the elderly, especially in men.

\section{Regulation of Sex Hormone-Binding Globulin Production}

There is a 20-fold variation in SHBG levels among individuals, while the level of SHBG in a given individual is relatively constant (5). SHBG levels are unrelated to meals or time of day (6). Table 1 lists those factors that are known to influence the level of SHBG in blood. In most cases, the mechanism is unknown.

SHBG levels decrease with increasing obesity (14) and rise with weight loss (15). SHBG is reduced in type 2 diabetes mellitus (T2DM), and the strength of the association is reduced,

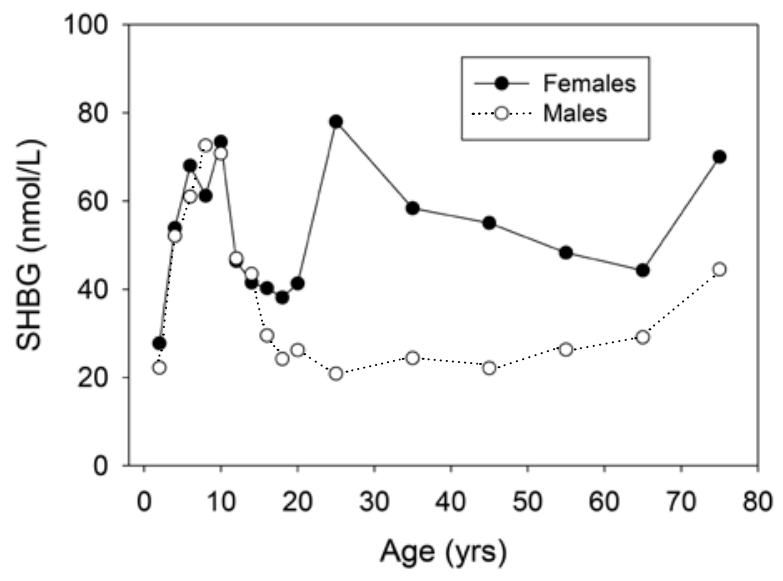

Figure 2. Sex hormone-binding globulin levels from birth to old age in males and females. Redrawn from Elmlinger et al (8). SHBG: sex hormone-binding globulin 
Aydın B and Winters SJ.

Sex Hormone-Binding Globulin in Children and Adolescents

but not eliminated, after adjustment for age and body mass index (BMI) (16). Notably, a low level of SHBG is a biomarker for the future development of the metabolic syndrome (MetS) (17), gestational diabetes (18), and T2DM (19).

\begin{tabular}{|l|l|}
\hline \multicolumn{2}{|l|}{$\begin{array}{l}\text { Table 1. Factors that influence the level of sex hormone-binding } \\
\text { globulin in blood }\end{array}$} \\
\hline Decrease & Increase \\
\hline Androgens & Estrogens \\
\hline Obesity & Pregnancy (Estrogens) \\
\hline Insulin resistance & Weight loss \\
\hline Metabolic syndrome & Alcoholic cirrhosis \\
\hline Type 2 diabetes mellitus & Hepatitis-B and hepatitis-C infection \\
\hline Gestational diabetes mellitus & Hemochromatosis \\
\hline Polycystic ovary syndrome & Hyperthyroidism \\
\hline $\begin{array}{l}\text { Non-alcoholic fatty liver } \\
\text { disease }\end{array}$ & Growth hormone deficiency \\
\hline Acromegaly & Acute intermittent porphyria \\
\hline Cushing's syndrome & First generation anticonvulsants \\
\hline $\begin{array}{l}\text { Congenital adrenal } \\
\text { hyperplasia }\end{array}$ & \\
\hline Hyperprolactinemia & \\
\hline Tumor necrosis factor alpha & \\
\hline Interleukin-1 beta & \\
\hline
\end{tabular}
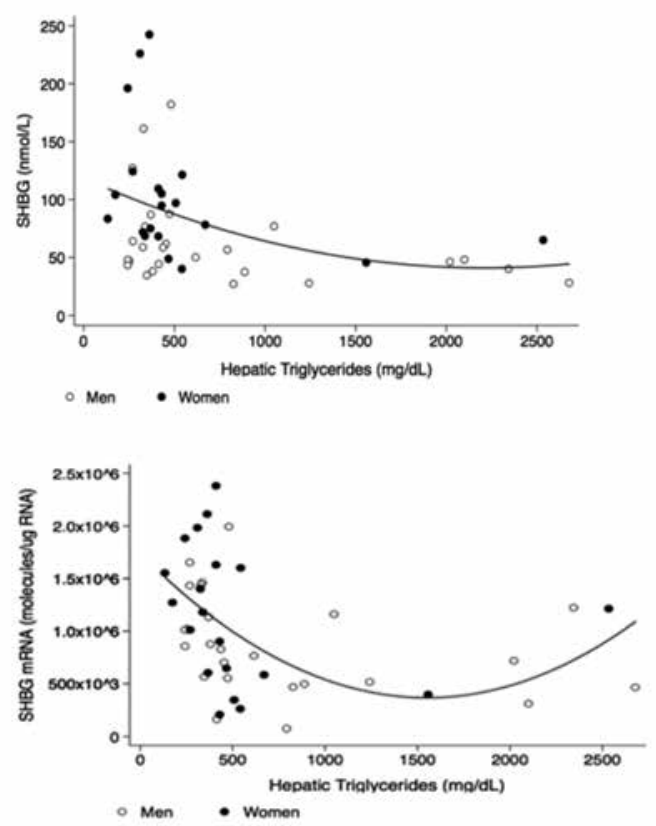

Figure 3. Associations between serum sex hormone-binding globulin levels $(A)$ and sex hormone-binding globulin messenger ribonucleic acid (B) with hepatic triglyceride levels in women and men undergoing partial hepatectomy. Redrawn from reference (38). SHBG: sex hormone-binding globulin, mRNA: messenger ribonucleic acid
Birkeland et al (20) reported that the level of SHBG represents an index of insulin resistance (IR), and many studies have confirmed this result (21). The traditional explanation for low SHBG levels in IR has been hyperinsulinemia (22). Studies have found an inverse correlation between SHBG and fasting (23), glucose-stimulated (24) or 24-hour mean insulin or C-peptide $(25,26)$, and SHBG levels increase when IR improves and insulin levels decline with weight loss (27), resistance exercise (28), or following treatment with insulin sensitizing drugs (29). Moreover, adding insulin to HepG2 hepatocarcinoma cells reduced their production of SHBG $(30,31)$, and insulin was reported to suppress $\mathrm{SHBG}$ messenger ribonucleic acid (mRNA) levels (31). A more recent study also using HepG2 cells, however, found no effect of insulin on SHBG secretion or mRNA levels. Instead, SHBG gene expression was reduced by the cytokines tumor necrosis factor-alpha (TNF $\alpha$ ) (32) or interleukin-1 beta (IL1 $\beta$ ) (33) and in transgenic mice that express SHBG after they were mated with obese, diabetic, hyperlipidemic $\mathrm{db} / \mathrm{db}$ mice with inactivating leptin receptor mutation (34).

The nuclear receptor hepatic nuclear factor-4 $\alpha$ (HNF4 $\alpha)$ activates the promoters of many genes that are expressed in the liver and plays a key role in lipid metabolism (35). Functional HNF4 $\alpha$-binding sites are found in over 140 genes, including those involved in the metabolism of glucose, lipids, and amino acids, and in the proximal promoter of the SHBG gene. Moreover, over-expression of HNF4 $\alpha$ in HepG2 cells by transient transfection increased the transcriptional rate of a SHBG-luciferase reporter (36). The effect of TNF $\alpha$ to suppress SHBG expression in vitro is mediated by HNF4 $\alpha$ (37) and there is a strong correlation between the expression levels of $H N F 4 \alpha$ and SHBG in human liver (38). Thus, HNF4 $\alpha$ regulation plays a central role in determining the level of SHBG in plasma.

Hepatic fat is associated with IR (39) and recent studies have linked hepatic steatosis to low SHBG. A study of subjects at risk for T2DM which found no relationship between SHBG and insulin secretion following glucose challenge concluded that the amount of liver fat was the strongest predictor of SHBG (40). Several studies have subsequently found a strong inverse correlation between the amount of liver fat and serum levels of SHBG $(41,42)$, and SHBG levels rise and liver fat decreases with weight loss (43). We recently found that serum SHBG and SHBG mRNA levels are low when the hepatic triglyceride concentration is elevated in a study of adult men and women undergoing hepatic resection as treatment for cancer (Figure 3) (38). In a recent study, Tong et al (44) reported that SHBG levels rose during short-term intensive insulin therapy in adults with newly-diagnosed T2DM which improved their lipid profiles and decreased liver enzymes [alanine aminotransferase (ALT), aspartate aminotransferase (AST), gamma glutamyltransferase (GGT)] and homeostatic model assessment-IR (HOMA-IR). Thus, the evidence to date suggests that excess hepatic fat is a 
Aydın B and Winters SJ.

Sex Hormone-Binding Globulin in Children and Adolescents

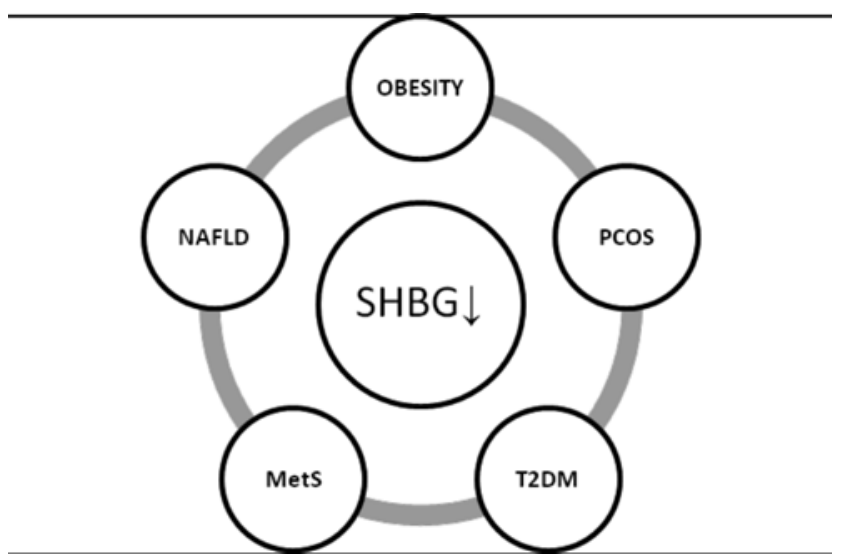

Figure 4. Relationship between obesity-related comorbidities and sex hormone-binding globulin levels. MetS: metabolic syndrome, NAFLD: non-alcoholic fatty liver disease, PCOS: polycystic ovary syndrome, T2DM: type 2 diabetes mellitus, SHBG: sex hormone-binding globulin

key determinant of low SHBG, although more research is needed.

\section{Clinical Disorders Affecting Sex Hormone-Binding Globulin}

There are several disorders which affect SHBG levels, and understanding these effects may be important clinically.

\section{Hyper- and Hypothyroidism}

SHBG levels increase dramatically in hyperthyroidism in proportion to the levels of thyroxine $\left(T_{4}\right)$ and triiodothyronine $\left(T_{3}\right)$ in children (45) as well as in adults. Values normalize when hyperthyroxinemia is treated. High SHBG levels will result in elevated levels of testosterone in both males and females, and may present a diagnostic challenge and lead to an unneeded evaluation for pituitary, adrenal, or gonadal disorders. High SHBG leads to elevation of luteinizing hormone $(\mathrm{LH})$ and estradiol and may produce breast enlargement in males (46). High SHBG levels result from thyroid hormone activation of the HNF4a gene promoter which, in turn, stimulates SHBG expression (47). SHBG is thus a marker of increased thyroid hormone bioactivity. This idea has been used clinically in patients with inappropriate thyroid-stimulating hormone (TSH) secretion with high free $T_{4} / T_{3}$ levels and TSH levels that are not suppressed. Some of these individuals have inactivating mutations of the thyroid hormone receptor, which disrupts feedback control of TSH secretion. These individuals may be recognized by their normal SHBG levels (48) and distinguished from patients with TSH-producing pituitary tumors who have hyperthyroxinemia and high SHBG (49). SHBG levels are reduced in hypothyroidism, which in men may be interpreted as testosterone deficiency.

\section{Adrenal Disorders}

SHBG levels are reduced in patients with Cushing's syndrome (50) and in patients treated with glucocorticoids (51).
Low SHBG together with adrenocorticotropic hormone (ACTH)mediated testosterone production may cause virilization in children, and contribute to delayed puberty, and anovulation and oligo-amenorrhea in ACTH-dependent Cushing's syndrome (52). In children treated with prednisone or dexamethasone for leukemia, the fall in SHBG occurred slowly over 4 weeks during which time $\mathrm{BMI}$ and leptin levels rose suggesting a connection to IR (51). Perhaps because of a tendency to abdominal adiposity (53), SHBG levels are also low in girls with congenital adrenal hyperplasia (54).

\section{Pituitary Disorders}

SHBG levels are elevated in patients with growth hormone deficiency (55) and are decreased in patients with acromegaly. To what extent these changes are mediated by insulin sensitivity and resistance is unknown. Lower SHBG levels have been reported in patients with hyperprolactinemia, but this association may also be influenced by the higher body fat with hypogonadism.

\section{Liver Disease}

SHBG is produced in the liver, and SHBG levels are affected by diseases of the liver through a variety of mechanisms. SHBG levels are elevated in patients with alcoholic cirrhosis. Alcohol damages the testis so that LH levels are elevated which in turn stimulate testicular aromatase and thereby estradiol production which increases SHBG. High SHBG may also be due to increased estrone and estradiol from the adrenals that is activated by stress and ACTH (56). Moreover, sulfatase (the enzyme which converts inactive estrogen sulfates to active estrogens) is increased in alcoholic liver. Amenorrheic women with both alcoholic and nonalcoholic cirrhosis, by contrast, tend to have low LH/follicle stimulating hormone and normal SHBG levels (57). SHBG levels are also markedly increased with hepatitis-B or hepatitis-C infection (58), while patients with liver disease due to hemochromatosis develop hypogonadotropic hypogonadism due to pituitary iron deposition and tend to have slightly elevated SHBG levels. Non-alcoholic fatty liver disease (NAFLD), a condition of increased hepatic triglycerides in the absence of excess alcohol consumption, is associated with increased visceral adipose tissue (VAT), IR, and dyslipidemia, and with low SHBG levels (41).

\section{Obesity and Related Comorbidities}

Childhood obesity is one of the most important health problems of our era due to its high prevalence and association with many chronic diseases and shorter life expectancy $(59,60)$. Recent studies have found alarming increases in the rates of childhood obesity and related comorbidities, such as T2DM, MetS, peripubertal hyperandrogenemia (HA), polycystic ovary syndrome (PCOS), NAFLD, and early puberty $(59,61,62,63,64)$. These disorders are inter-related, and their etiology and pathogenesis are multifactorial and controlled by 
Aydın B and Winters SJ.

Sex Hormone-Binding Globulin in Children and Adolescents

genetic factors, the intrauterine environment, and an unhealthy lifestyle (63). Since these conditions increase the risk of early cardiovascular disease (CVD), finding effective ways to identify at-risk children as early as possible is an important goal. SHBG is a promising biomarker (Figure 4) because SHBG levels are unaffected by meals or time of day, there is no influence of sex hormones in prepubertal children, and SHBG can be readily measured in a finger-stick blood sample. Many studies have linked lower circulating levels of SHBG to obesity, IR, MetS, T2DM, PCOS, and NAFLD $(21,60,65)$. These associations may be explained by the idea that low SHBG is a marker for IR.

\section{Type 2 Diabetes Mellitus and Sex Hormone-Binding Globulin}

SHBG levels are low in adults with T2DM, and many studies show that low levels predict diabetes risk $(19,66,67)$. The relationship is reduced, but maintained, after controlling for obesity. T2DM is increasingly diagnosed in children as young as age 10 , and now accounts for $20 \%$ to $50 \%$ of new-onset diabetes in children (64). In the U.S., it disproportionately affects Latino and Black children. Several studies showed that weight loss through calorie restriction and metformin treatment, in combination with lifestyle changes, increases serum SHBG levels in adolescents at risk for developing diabetes (68). In those studies, insulin levels decreased with intervention due to improvement in insulin sensitivity.

It has been suggested that SHBG may have a causal role in the risk of T2DM since Mendelian randomization studies have reported that carrying specific SHBG single-nucleotide polymorphisms (SNPs) affects the risk of T2DM $(19,66)$. Carriers of rs6259 polymorphism were shown to have higher SHBG levels and a lower risk of T2DM, and rs6257 SNP carriers were reported to have lower SHBG levels and higher risk of T2DM (19). In another larger study including 86138 adults, presence of the rs1799941 SNP was associated with increased SHBG concentrations and reduced risk of T2DM after correction for age, sex, and BMI (66). In a recent study, Wang et al (69) showed that circulating SHBG levels were predictive for

\section{SHBG in South Asian Girls \& Boys}

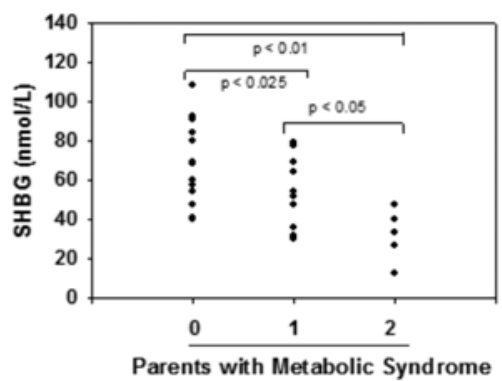

Figure 5. Serum levels of sex hormone-binding globulin in South Asian Indian children according to the diagnosis of Metabolic syndrome in their parents; redrawn from reference (86). SHBG: sex hormone-binding globulin future IR in healthy young Finnish adults, whereas Mendelian randomization suggested minor, if any, causal effects.

\section{Metabolic Syndrome and Sex Hormone-Binding Globulin}

MetS is a combination of risk factors for increased CVD morbidity and mortality that includes central obesity, hypertension, dyslipidemia, and impaired glucose metabolism. MetS is increasingly recognized in children and adolescents, but the diagnostic criteria for this age group remain controversial (70). Furthermore, no accepted definition applies to all ethnic groups because ethnic variations exist in the distribution of MetS components in children $(71,72,73,74)$.

As in adults, SHBG levels are low in children and adolescents diagnosed with MetS $(75,76,77)$. In a cross-sectional study of 815 school children in Spain by de Oya et al (77), SHBG levels were lower in those adolescents with MetS or with some MetS features, such as abdominal obesity, high blood pressure or high insulin and low high density lipoprotein cholesterol (HDL-C) levels. Agirbasli et al (78) reported that low SHBG was a significant predictor of low HDL-C levels in Turkish children and adolescents. Detailed metabolic profiling of 6475 young adults from two population-based Finnish cohorts revealed a strong association between SHBG and circulating lipids and metabolites reflecting the degree of adiposity and IR. Low SHBG predicted the development of IR in early adulthood, and these associations remained robust after adjustment for baseline adiposity, insulin and testosterone levels (69). Glueck et al (65) demonstrated that low SHBG levels in U.S. schoolgirls at age 14 were a positive predictor for the development of MetS 10 years later. Thus, SHBG may be valuable biomarker for MetS risk in children long before the disease progresses.

There are substantial racial and ethnic differences in body composition for a given BMl between subjects of the same sex and age. Previous studies have documented a genetic predisposition for MetS $(79,80)$ and there is evidence that SHBG levels, like MetS components, vary by ethnicity (Table 2). In the national health and nutrition examination survey (NHANES) study, SHBG levels were lower in MexicanAmerican males age 12-19 than in non-Hispanic blacks and whites (81). Abdelrahaman et al (82) found that high levels of SHBG are more common among healthy African American prepubertal boys, a racial group with more subcutaneous but less VAT than their white peers. Hergenc et al (83) reported that Turkish middle-aged adults have lower SHBG levels compared with Germans, and most of the difference in HDL-C between Germans and Turks was explained by ethnicity independent of obesity markers, insulin, and sex hormones. The MELEN study of 751 Turkish adult women and men, with a mean age of 55 years, found that $34 \%$ had MetS (84), while a recent study of German women reported a prevalence of $23.1 \%$ (85). South Asian Indians are an ethnic group at especially high risk for MetS and T2DM even though they have low BMI. Krishnasamy et al (86) found that prepubertal South Asian Indian children 
Aydın B and Winters SJ.

Sex Hormone-Binding Globulin in Children and Adolescents

with one parent with MetS had 24\% lower SHBG levels, and with both parents affected had 55\% lower SHBG levels (Figure 5). Their study also demonstrated that SHBG levels were inversely related to waist circumference and to BMI percentile in those children. Significant associations were reported between SHBG (rs6257), cholesterol ester transfer protein (rs708272) polymorphisms and high triglycerides, low HDL-C and high low-density lipoprotein cholesterol levels in a cohort of 365 Turkish children and adolescents (87). Additionally, White et al (88) reported that SNPs located in the SHBG gene (rs1799941) were associated with MetS in children. They found that association with MetS remained after sequential adjustment for each MetS component, indicating that the identified association was not being driven by any single trait. The A allele of rs1799941 was associated with a significant increase in SHBG levels in control subjects, while there was no association between rs1799941 and SHBG levels in children with MetS.

Peripubertal Hyperandrogenaemia, Adolescent Polycystic Ovary Syndrome and Sex Hormone-Binding Globulin

PCOS is the most common endocrine disorder among reproductive-aged women, and the most common cause of infertility in young women. PCOS is characterized by $\mathrm{HA}$, menstrual dysfunction, and polycystic ovarian morphology, and arises as a complex trait due to inherited and environmental factors. Adolescents with PCOS are more insulin resistant and hyperinsulinemic compared to weight-matched non-hyperandrogenemic girls (89). SHBG levels are reduced in PCOS resulting in a higher portion of biologically active androgen, and an increased number of
(TAAAA)n repeats in the SHBG promoter region may be a susceptibility locus for PCOS (90) although this association is controversial (91). The clinical manifestations of PCOS often begin during puberty, but the anovulation and acne that often occur in healthy teenage girls make the PCOS diagnosis challenging in adolescents. Therefore, biochemical evidence of HA, including low SHBG levels, is important in the evaluation of adolescent PCOS (92).

SHBG levels are low in obese and overweight peripubertal girls, and weight loss is associated with a decrease in testosterone and an increase in SHBG levels $(93,94)$. Not all peripubertal obese girls have elevated androgens, however, and not all adolescents diagnosed with PCOS are obese or overweight, suggesting that obesity per se is not sufficient to produce HA (95). Teenage daughters of PCOS patients are more likely to have features of the MetS, and to be hyperinsulinemic (96), have larger ovaries beginning at Tanner stage 1 , and by Tanner stage $V$ have lower SHBG levels than daughters born to control women (97).

The prevalence of PCOS in women born small for gestational age (SGA) is twice as high as in women born with normal weight (98). Girls born SGA with catchup growth were shown to display more visceral fat as compared to age- and BMI- matched children born at normal weight (99) and have lower SHBG concentrations and an exaggerated adrenarche between the ages of 6 and 8 years (100). Longitudinal studies revealed that metformin-treated low birth weight children were leaner, had less IR and higher SHBG levels than placebo-treated children, and in low birthweight girls, the increase in SHBG was followed by a delay of menarche (68).

\begin{tabular}{|l|l|l|l|}
\hline \multicolumn{3}{|l|}{ Table 2. Studies evaluating ethnic and racial differences in serum sex hormone-binding globulin levels in children and adolescents } \\
\hline Author, year (reference) & Study population (n) & Age range (years) & Conclusion \\
\hline Hui et al, 2003 (121) & $\begin{array}{l}\text { Healthy children with roughly equal } \\
\text { numbers of African American and white } \\
\text { boys and girls (n=232) }\end{array}$ & $4-16$ & $\begin{array}{l}\text { SHBG did not differ between racial } \\
\text { groups }\end{array}$ \\
\hline Abdelrahaman et al, 2005 (82) & African American and white boys (n=47) & $5-9$ & $\begin{array}{l}\text { High levels of SHBG were more } \\
\text { common among African American } \\
\text { boys than white boys }\end{array}$ \\
\hline Danielson et al, 2010 (122) & $\begin{array}{l}\text { Racially/ethnically diverse individuals } \\
\text { with T1DM diagnosed at age <18 years } \\
\text { (n=79) (32.9\% NHW, 46.8\% NHB, 12.7\% } \\
\text { Hispanic, 7.6\% other/mixed) }\end{array}$ & $\begin{array}{l}\text { Insulin resistance, estimated by } \\
\text { eGDR, was greater in minorities with } \\
\text { T1DM than in NHW probands; eGDR } \\
\text { was negatively associated with SHBG }\end{array}$ \\
\hline Hannon and Arslanian, 2012 (123) & $\begin{array}{l}\text { African American and white obese } \\
\text { females (n=22) }\end{array}$ & $\begin{array}{l}\text { SHBG levels were not significantly } \\
\text { different between white and blacks }\end{array}$ \\
\hline Lopez et al, 2013 (81) & $\begin{array}{l}\text { NHB, NHW and Hispanic males (n=134) } \\
\text { Wolfgram et al, 2014 (108) }\end{array}$ & $\begin{array}{l}\text { Non-obese NHW and Hispanic girls } \\
\text { (n=32) }\end{array}$ & $\begin{array}{l}\text { SHBG levels were lower in Hispanic } \\
\text { males than in NHB and NHW }\end{array}$ \\
\hline eGDR: estimated glucose disposal rate, NHB: non-Hispanic black, NHW: non-Hispanic white, T1DM: type 1 diabetes mellitus, SHBG: sex hormone-binding globulin \\
\hline
\end{tabular}


Aydin B and Winters SJ.

Sex Hormone-Binding Globulin in Children and Adolescents

\section{Non-alcoholic Fatty Liver Disease and Sex Hormone-Binding Globulin}

NAFLD has become the most common form of liver disease in childhood. The presence and severity of NAFLD are associated with an increased incidence of CVD, independent of established risk factors, and NAFLD was suggested as not only a marker of CVD risk but also an important player in CVD pathogenesis (101). Early diagnosis and treatment is crucial, but most children with NAFLD remain undiagnosed (63). While liver biopsy is the gold standard for diagnosis, the European Society for Pediatric Gastroenterology, Hepatology and Nutrition instead recommends abdominal ultrasound and liver function tests for all obese children (102). Large-scale ultrasound may not be a cost-effective approach, however, and liver transaminase (ALT, AST) elevations were a poor predictor, especially in the earliest stages $(60,102)$. Additionally, the serum GGT level may be a marker of oxidative stress rather than a specific marker of NAFLD-induced liver disease (103).

Previous studies have shown that liver fat is a stronger predictor of SHBG than is total body fat. Serum SHBG levels were lower in high-grade NAFLD patients with T2DM than in diabetics without NAFLD (104), and lower SHBG levels were found in adult (105) and adolescent (106) PCOS subjects with NAFLD compared with PCOS subjects without NAFLD (40). Moreover, those women with PCOS and NAFLD are more insulin resistant than are PCOS women without evidence for hepatic steatosis by ultrasound (107). Wolfgram et al (108) showed significant correlations between hepatic proton density fat fraction measured by magnetic resonance imaging and SHBG blood levels in non-obese Hispanic middle school girls. Finally, SHBG levels were shown to rise as liver fat decreases with weight loss (43). In the light of these findings, SHBG represents an alternative marker for pediatric NAFLD risk stratification and in certain children at higher risk for NAFLD and MetS, may be a useful biomarker perhaps prior to the development of obesity.

\section{Early Puberty and Sex Hormone-Binding Globulin}

There is accumulating evidence that puberty in girls is occurring at an earlier age, and the obesity epidemic is an important factor in this phenomenon (109). SHBG may function during childhood to restrict the actions of sex steroids until puberty at which time sex steroid levels increase in concert with a fall in plasma SHBG levels such that the overall result is a progressive increase in both total and free and hormone levels. The mechanism for the decline in SHBG at puberty is not well understood but appears to be metabolic rather than hormonal since the decrease occurs in boys with hypopituitarism (11). Moreover, insulin sensitivity declines in early normal puberty (110) which could lead to lower SHBG levels. In a cross-sectional study on 132 healthy Caucasian children and adolescents, SHBG was a strong predictor of insulin sensitivity after adjustment for puberty, fat mass, and aerobic fitness (111). In that study, the authors reported a significant negative association between metabolic risk and SHBG levels after adjustment for relevant confounders, and hypothesized that SHBG integrates the marked changes in glucose metabolism and body composition that occur during the pubertal transition and might be valuable in the assessment of CVD risk during puberty. Pinkney et al (10) reported that girls with lower SHBG levels at 5 years of age reached Tanner stage 2 earlier, tended to have earlier increases in LH secretion, and an earlier age at peak height velocity and menarche. They reported negative correlations between SHBG and adiposity, insulin, IGF-I, CRP, and leptin, and positive associations between adiponectin and SHBG (10). Sorensen et al (112) found that, after adjustment for BMI and pubertal stage, girls with central precocious puberty have lower SHBG levels compared with healthy controls, and the decline in SHBG levels during puberty is associated with increasing fat mass in healthy children and adolescents.

Although studies tend to indicate a relationship between obesity and early puberty in girls, the association in boys is controversial. Some authors report advanced sexual maturation in obese boys $(113,114)$, some describe normal pubertal timing (115), while others report delayed testicular development with obesity $(116,117)$. The reason for these contradictory findings is uncertain but might be due to differences in the study populations, pubertal markers, and cut-off points for defining obesity. Studies have shown that SHBG levels are lower in obese boys than in their normal weight peers $(23,115)$. Pinkney et al $(10)$ reported that boys with lower SHBG levels at age 5 years reached Tanner stage 2 earlier, but there was no relationship between SHBG and earlier onset of $\mathrm{LH}$ secretion or age at peak height velocity. Most studies report lower total testosterone levels in obese boys during pubertal progression (118) which can be explained by lower SHBG whereas SHBG and total testosterone are unrelated in prepubertal boys (82).

Denburg et al (119) reported lower SHBG levels and decreased insulin sensitivity in boys with premature pubarche (PP) than in age- and BMI-matched peers. They showed significant correlations between SHBG and measures of insulin sensitivity in boys with PP and controls, and suggested that SHBG may be a marker for IR. On the other hand, Potau et al (120) found that SHBG levels and measures of the glucose and insulin response to an oral glucose challenge were comparable in boys with PP and controls, and concluded that PP in boys may be regarded as a variant of normal development.

In conclusion, evidence is accumulating that low SHBG levels are an indicator of IR, and SHBG may be an easy-to-measure and clinically useful biomarker for the early identification of children who are destined to develop obesity-related chronic diseases. Further research is needed to understand how SHBG is regulated in children. Moreover, studies with respect to race 
and ethnicity are needed to establish SHBG reference ranges for children and adolescents. Finally, whether SHBG is solely a biomarker or rather participates actively in the pathogenesis of metabolic disease remains to be elucidated.

Peer-review: Internal peer-reviewed.

\section{Authorship Contributions}

Concept: Stephen J. Winters, Design: Stephen J. Winters, Data Collection and/or Processing: Stephen J. Winters, Banu Aydın, Analysis and/or Interpretation: Stephen J. Winters, Banu Aydın, Literature Research: Stephen J. Winters, Banu Aydın, Writing: Stephen J. Winters, Banu Aydın.

Financial Disclosure: BA is supported through The Scientific and Technical Research Council of Turkey (TUBITAK) (International Postdoctoral Research Scholarship Program). SJW is supported in part by a gift from the Walter F. and Avis Jacobs Foundation.

\section{References}

1. Hammond GL, Bocchinfuso WP. Sex hormone-binding globulin: gene organization and structure/function analyses. Horm Res 1996:45:197-201.

2. Dunn JF, Nisula BC, Rodbard D. Transport of steroid hormones: binding of 21 endogenous steroids to both testosteronebinding globulin and corticosteroid-binding globulin in human plasma. J Clin Endocrinol Metab 1981;53:58-68.

3. Vos MJ, Mijnhout GS, Rondeel JM, Baron W, Groeneveld $\mathrm{PH}$. Sex hormone binding globulin deficiency due to a homozygous missense mutation. J Clin Endocrinol Metab 2014;99:1798-1802. Epub 2014 Jun 17

4. Hogeveen KN, Cousin P, Pugeat M, Dewailly D, Soudan B, Hammond GL. Human sex hormone-binding globulin variants associated with hyperandrogenism and ovarian dysfunction. J Clin Invest 2002;109:973-981.

5. de Ronde $W$, van der Schouw YT, Pierik FH, Pols HA, Muller M, Grobbee DE, Gooren LJ, Weber RF, de Jong $\mathrm{FH}$. Serum levels of sex hormone-binding globulin (SHBG) are not associated with lower levels of non-SHBG-bound testosterone in male newborns and healthy adult men. Clinl Endocrinol (Oxf) 2005;62:498-503.

6. Jin Z, Guan X, Gao H, Shang L, Gao M, Su D, Li W. The change in sex hormone binding globulin and the influence by gestational diabetes mellitus in fetal period. Gynecol Endocrinol 2009;25:647-652.

7. Liu B, Xu Y, Liang JM, Voss C, Xiao HY, Sheng WY, Sun $\mathrm{YH}$, Wang ZL. Intrauterine insulin resistance in fetuses of overweight mothers. J Obstet Gynaecol Res 2013;39:132138. Epub 2012 Jun 13

8. Elmlinger MW, Kuhnel W, Wormstall H, Döller PC. Reference intervals for testosterone, androstenedione and SHBG levels in healthy females and males from birth until old age. Clin Lab 2005;51:625-632.

9. Pierik FH, Deddens JA, Burdorf A, de Muinck Keizer-Schrama SM, Jong FH, Weber RF. The hypothalamus-pituitary-testis axis in boys during the first six months of life: a comparison of cryptorchidism and hypospadias cases with controls. Int J Androl 2009:32:453-461. Epub 2008 Mar 10

10. Pinkney J, Streeter A, Hosking J, Mostazir M, Jeffery A, Wilkin T. Adiposity, chronic inflammation, and the prepubertal decline of sex hormone binding globulin in children: evidence for associations with the timing of puberty (Earlybird 58). J Clin Endocrinol Metab 2014;99:3224-3232. Epub 2014 Jun 13

11. Garcés C, Oya Id, Lasunción MA, López-Simón L, Cano B, de Oya M. Sex hormone-binding globulin and lipid profile in pubertal children. Metabolism 2010;59:166-171. Epub 2009 Sep 17

12. Belgorosky A, Martinez A, Domene H, Heinrich JJ, Bergada C, Rivarola MA. High serum sex hormone-binding globulin (SHBG) and low serum non-SHBG-bound testosterone in boys with idiopathic hypopituitarism: effect of recombinant human growth hormone treatment. J Clin Endocrinol Metab 1987;65:1107-1111.

13. Murphy A, Cropp CS, Smith BS, Burkman RT, Zacur HA. Effect of low-dose oral contraceptive on gonadotropins, androgens, and sex hormone binding globulin in nonhirsute women. Fertil Steril 1990;53:35-39.

14. Glass AR, Swerdloff RS, Bray GA, Dahms WT, Atkinson $\mathrm{RL}$. Low serum testosterone and sex-hormone-bindingglobulin in massively obese men. J Clin Endocrinol Metab 1977;45:1211-1219

15. Guzick DS, Wing R, Smith D, Berga SL, Winters SJ. Endocrine consequences of weight loss in obese, hyperandrogenic, anovulatory women. Fertil Steril 1994;61:598-604.

16. Barrett-Connor E, Khaw KT, Yen SS. Endogenous sex hormone levels in older adult men with diabetes mellitus. Am J Epidemiol 1990;132:895-901.

17. Brand JS, van der Tweel I, Grobbee DE, Emmelot-Vonk MH, van der Schouw YT. Testosterone, sex hormone-binding globulin and the metabolic syndrome: a systematic review and meta-analysis of observational studies. Int $\mathrm{J}$ Epidemiol 2011;40:189-207. Epub 2010 Sep 24

18. Veltman-Verhulst SM, van Haeften TW, Eijkemans MJ, de Valk HW, Fauser BC, Goverde AJ. Sex hormone-binding globulin concentrations before conception as a predictor for gestational diabetes in women with polycystic ovary syndrome. Hum Reprod 2010;25:3123-3128. Epub 2010 Oct 13

19. Ding EL, Song Y, Manson JE, Hunter DJ, Lee CC, Rifai N, Buring JE, Gaziano JM, Liu S. Sex hormone-binding globulin and risk of type 2 diabetes in women and men. N Engl J Med 2009;361:1152-1163. Epub 2009 Aug 5

20. Birkeland KI, Hanssen KF, Torjesen PA, Vaaler S. Level of sex hormone-binding globulin is positively correlated with insulin sensitivity in men with type 2 diabetes. J Clin Endocrinol Metab 1993;76:275-278.

21. Wallace IR, McKinley MC, Bell PM, Hunter SJ. Sex hormone binding globulin and insulin resistance. Clin Endocrinol 2013:78:321-329.

22. Pugeat $M$, Crave JC, Elmidani M, Nicolas MH, Garoscio-Cholet M, Lejeune H, Dechaud H, Tourniaire J. Pathophysiology of sex hormone binding globulin (SHBG): relation to insulin. J Steroid Biochem Mol Biol 1991;40:841-849.

23. Gascon F, Valle M, Martos R, Ruz FJ, Rios R, Montilla P, Canete R. Sex hormone-binding globulin as a marker for hyperinsulinemia and/or insulin resistance in obese children. Eur J Endocrinol 2000;143:85-89.

24. Galloway PJ, Donaldson MD, Wallace AM. Sex hormone binding globulin concentration as a prepubertal marker for hyperinsulinaemia in obesity. Arch Dis Child 2001;85:489-491.

25. Toscano V, Balducci R, Bianchi P, Guglielmi R, Mangiantini $A$, Sciarra F. Steroidal and non-steroidal factors in plasma sex hormone binding globulin regulation. J Steroid Biochem Mol Biol 1992;43:431-437. 
26. Katsuki A, Sumida Y, Murashima S, Fujii M, Ito K, Tsuchihashi K, Murata K, Yano Y, Shima T. Acute and chronic regulation of serum sex hormone-binding globulin levels by plasma insulin concentrations in male noninsulin-dependent diabetes mellitus patients. J Clin Endocrinol Metab 1996;81:2515-2519.

27. Pasquali R, Vicennati V, Scopinaro N, Marinari G, Simonelli A, Flamia R, Casimirri F, Gagliardi L. Achievement of near-normal body weight as the prerequisite to normalize sex hormonebinding globulin concentrations in massively obese men. Int J Obes Relat Metab Disord 1997;21:1-5.

28. Roberts CK, Croymans DM, Aziz N, Butch AW, Lee CC. Resistance training increases SHBG in overweight/obese, young men. Metabolism 2013;62:725-733. Epub 2013 Jan 12

29. Nestler JE, Powers LP, Matt DW, Steingold KA, Plymate SR, Rittmaster RS, Clore JN, Blackard WG. A direct effect of hyperinsulinemia on serum sex hormone-binding globulin levels in obese women with the polycystic ovary syndrome. J Clin Endocrinol Metab 1991;72:83-89.

30. Plymate SR, Matej LA, Jones RE, Friedl KE. Inhibition of sex hormone-binding globulin production in the human hepatoma (Hep G2) cell line by insulin and prolactin. J Clin Endocrinol Metab 1988;67:460-464.

31. Loukovaara $M$, Carson $M$, Adlercreutz $H$. Regulation of production and secretion of sex hormone-binding globulin in HepG2 cell cultures by hormones and growth factors. J Clin Endocrinol Metab 1995;80:160-164.

32. Simo R, Barbosa-Desongles A, Lecube A, Hernandez $C$ Selva DM. Potential role of tumor necrosis factor-alpha in downregulating sex hormone-binding globulin. Diabetes 2012;61:372-382. Epub 2011 Dec 30

33. Simo R, Barbosa-Desongles A, Hernandez C, Selva DM. IL1beta down-regulation of sex hormone-binding globulin production by decreasing HNF-4alpha via MEK-1/2 and JNK MAPK pathways. Mol Endocrinol 2012;26:1917-1927. Epub 2012 Aug 17

34. Saez-Lopez C, Rivera-Gimenez M, Hernandez C, Simo R, Selva DM. SHBG-C57BL/ksJ-db/db: a new mouse model to study SHBG expression and regulation during obesity development. Endocrinology 2015;156:4571-4581. Epub 2015 Oct 6

35. Schrem H, Klempnauer J, Borlak J. Liver-enriched transcription factors in liver function and development. Part II: the C/EBPs and D site-binding protein in cell cycle control, carcinogenesis, circadian gene regulation, liver regeneration, apoptosis, and liver-specific gene regulation. Pharmacol Rev 2004;56:291-330.

36. Janne M, Hammond GL. Hepatocyte nuclear factor-4 controls transcription from a TATA-less human sex hormone-binding globulin gene promoter. J Biol Chem 1998;273:34105-34114.

37. Simo R, Barbosa-Desongles A, Saez-Lopez C, Lecube A, Hernandez C, Selva DM. Molecular Mechanism of TNFalpha-induced down-regulation of SHBG expression. Mol Endocrinol 2012;26:438-446. Epub 2012 Feb 2

38. Winters SJ, Gogineni J, Karegar M, Scoggins C, Wunderlich CA, Baumgartner R, Ghooray DT. Sex hormone-binding globulin gene expression and insulin resistance. J Clin Endocrinol Metab 2014;99:2780-2788.

39. Stefan N, Kantartzis K, Haring HU. Causes and metabolic consequences of Fatty liver. Endocr Rev 2008;29:939-960. Epub 2008 Aug 21

40. Peter A, Kantartzis $K$, Machann J, Schick $F$, Staiger $H$, Machicao F, Schleicher E, Fritsche A, Haring HU, Stefan N. Relationships of circulating sex hormone-binding globulin with metabolic traits in humans. Diabetes 2010;59:31673173. Epub 2010 Sep 14
41. Hua $X$, Sun $Y$, Zhong $Y$, Feng $W$, Huang $H$, Wang $W$, Zhang T, $\mathrm{Hu}$ Y. Low serum sex hormone-binding globulin is associated with nonalcoholic fatty liver disease in type 2 diabetic patients. Clin Endocrinol (Oxf) 2014;80:877-883. Epub 2013 Dec 5

42. Lazo M, Zeb I, Nasir K, Tracy RP, Budoff MJ, Ouyang P, Vaidya $D$. Association between endogenous sex hormones and liver fat in a multiethnic study of atherosclerosis. Clin Gastroenterol Hepatol 2015;13:1686-1693.

43. Stefan N, Schick F, Haring HU. Sex hormone-binding globulin and risk of type 2 diabetes. N Engl J Med 2009;361:26752676. Epub 2015 Jan 13

44. Tong G, Hua X, Zhong Y, Zhang K, Gu G, Feng W, Huang $H$, Wang W, Li L, Sun Y, Zhang T, Hu Y. Intensive insulin therapy increases sex hormone-binding globulin in newly diagnosed type 2 diabetic patients. Eur J Endocrinol 2014;170:237-245.

45. Nielsen J, Jensen RB, Juul A. Increased sex hormonebinding globulin levels in children and adolescents with thyrotoxicosis. Horm Res Paediatr 2013;79:157-161. Epub 2013 Mar 27

46. Jayapaul M, Williams MR, Davies DP, Large DM. Recurrent painful unilateral gynaecomastia-interactions between hyperthyroidism and hypogonadism. Andrologia 2006;38:31-33.

47. Selva DM, Hammond GL. Thyroid hormones act indirectly to increase sex hormone-binding globulin production by liver via hepatocyte nuclear factor-4alpha. J Mol Endocrinol 2009;43:19-27. Epub 2009 Mar 31

48. Beck-Peccoz P, Roncoroni R, Mariotti S, Medri G, Marcocci C, Brabant G, Forloni F, Pinchera A, Faglia G. Sex hormonebinding globulin measurement in patients with inappropriate secretion of thyrotropin (IST): evidence against selective pituitary thyroid hormone resistance in nonneoplastic IST. $J$ Clin Endocrinol Metab 1990;71:19-25.

49. Chantler D, Moran C, Schoenmakers E, Cleland S, Panarelli $\mathrm{M}$. Resistance to thyroid hormone--an incidental finding. BMJ Case Rep 2012:2012.

50. Kaltsas GA, Korbonits M, Isidori AM, Webb JA, Trainer PJ, Monson JP, Besser GM, Grossman AB. How common are polycystic ovaries and the polycystic ovarian syndrome in women with Cushing's syndrome? Clin Endocrinol (Oxf) 2000;53:493-500.

51. Wallace AM, Tucker P, Williams DM, Hughes IA, Ahmed SF. Short-term effects of prednisolone and dexamethasone on circulating concentrations of leptin and sex hormone-binding globulin in children being treated for acute lymphoblastic leukaemia. Clin Endocrinol (Oxf) 2003;58:770-776.

52. Dupuis CC, Storr HL, Perry LA, Ho JT, Ahmed L, Ong KK, Dunger DB, Monson JP, Grossman AB, Besser GM, Savage MO. Abnormal puberty in paediatric Cushing's disease: relationship with adrenal androgen, sex hormone binding globulin and gonadotrophin concentrations. Clin Endocrinol (Oxf) 2007;66:838-843. Epub 2007 Apr 15

53. Kim MS, Ryabets-Lienhard A, Dao-Tran A, Mittelman SD, Gilsanz V, Schrager SM, Geffner ME. Increased abdominal adiposity in adolescents and young adults with classical congenital adrenal hyperplasia due to 21-hydroxylase deficiency. J Clin Endocrinol Metab 2015;100:1153-1159. Epub 2015 Jun 10

54. Zamrazilova L, Dvorakova M, Lisa L, Starka L, Hampl R. Sex hormone-binding globulin in congenital adrenal hyperplasia. Horm Mol Biol Clin Investig 2010;1:89-93.

55. Menezes M, Salvatori R, Melo LD, Rocha IE, Oliveira CR, Pereira RM, Souza AH, Valença EH, Melo EV, Campos VC, Costa FO, Aguiar-Oliveira $\mathrm{MH}$. Prolactin and sex steroids levels in congenital lifetime isolated $\mathrm{GH}$ deficiency. Endocrine 2013;44:207-211. Epub 2013 Feb 10 
56. Van Thiel DH, Loriaux DL. Evidence for an adrenal origin of plasma estrogens in alcoholic men. Metabolism 1979;28:536-541.

57. Bell H, Raknerud N, Falch JA, Haug E. Inappropriately low levels of gonadotrophins in amenorrhoeic women with alcoholic and non-alcoholic cirrhosis. Eur J Endocrinol 1995;132:444-449.

58. Rao J, Danoff A, Bini EJ. Elevated sex hormone binding globulin levels may contribute to sexual dysfunction in men with chronic hepatitis C virus infection. J Clin Gastroenterol 2009;43:94-95.

59. Marcovecchio ML, Chiarelli F. Metabolic syndrome in youth: chimera or useful concept? Curr Diab Rep 2013;13:56-62.

60. Morandi A, Maffeis C. Predictors of metabolic risk in childhood obesity. Horm Res Paediatr 2014;82:3-11. Epub 2014 Jun 11

61. Burt Solorzano CM, McCartney CR. Obesity and the pubertal transition in girls and boys. Reproduction 2010;140:399-410.

62. Steinberger J, Daniels SR, Eckel RH, Hayman L, Lustig RH, McCrindle B, Mietus-Snyder ML; American Heart Association Atherosclerosis, Hypertension, and Obesity in the Young Committee of the Council on Cardiovascular Disease in the Young; Council on Cardiovascular Nursing; and Council on Nutrition, Physical Activity, and Metabolism. Progress and challenges in metabolic syndrome in children and adolescents: a scientific statement from the American Heart Association Atherosclerosis, Hypertension, and Obesity in the Young Committee of the Council on Cardiovascular Disease in the Young; Council on Cardiovascular Nursing; and Council on Nutrition, Physical Activity, and Metabolism. Circulation 2009;119:628-647. Epub 2009 Jan 12

63. Alterio A, Alisi A, Liccardo D, Nobili V. Non-alcoholic fatty liver and metabolic syndrome in children: a vicious circle. Horm Res Paediatr 2014;82:283-289. Epub 2014 Oct 15

64. Pulgaron ER, Delamater AM. Obesity and type 2 diabetes in children: epidemiology and treatment. Current Diab Rep 2014;14:508.

65. Glueck CJ, Morrison JA, Daniels S, Wang P, Stroop D. Sex hormone-binding globulin, oligomenorrhea, polycystic ovary syndrome, and childhood insulin at age 14 years predict metabolic syndrome and class III obesity at age 24 years. J Pediatr 2011;159:308-313. Epub 2011 Mar 1

66. Perry JR, Weedon MN, Langenberg C, Jackson AU, Lyssenko $V$, Sparsø T, Thorleifsson G, Grallert H, Ferrucci L, Maggio M, Paolisso G, Walker M, Palmer CN, Payne F, Young E, Herder C, Narisu N, Morken MA, Bonnycastle LL, Owen KR, Shields B, Knight B, Bennett A, Groves CJ, Ruokonen A, Jarvelin MR, Pearson E, Pascoe L, Ferrannini E, Bornstein SR, Stringham HM, Scott LJ, Kuusisto J, Nilsson P, Neptin M, Gjesing AP, Pisinger C, Lauritzen T, Sandbaek A, Sampson M; MAGIC, Zeggini $E$, Lindgren $C M$, Steinthorsdottir $V$, Thorsteinsdottir U, Hansen T, Schwarz P, Illig T, Laakso M, Stefansson K, Morris AD, Groop L, Pedersen O, Boehnke M, Barroso I, Wareham NJ, Hattersley AT, McCarthy MI, Frayling TM. Genetic evidence that raised sex hormone binding globulin (SHBG) levels reduce the risk of type 2 diabetes. Hum Mol Genet 2010;19:535-544. Epub 2009 Nov 18

67. Shin JY, Kim SK, Lee MY, Kim HS, Ye BI, Shin YG, Baik SK, Chung $\mathrm{CH}$. Serum sex hormone-binding globulin levels are independently associated with nonalcoholic fatty liver disease in people with type 2 diabetes. Diabetes Res Clin Pract 2011;94:156-162. Epub 2011 Sep 8

68. Ibanez L, Valls C, Ong K, Dunger DB, de Zegher F. Metformin therapy during puberty delays menarche, prolongs pubertal growth, and augments adult height: a randomized study in low-birth-weight girls with early-normal onset of puberty. J Clin Endocrinol Metab 2006;91:2068-2073. Epub 2006 Feb 21
69. Wang $Q$, Kangas AJ, Soininen $P$, Tiainen M, Tynkkynen $T$, Puukka K, Ruokonen A, Viikari J, Kähönen M, Lehtimäki T, Salomaa V, Perola M, Davey Smith G, Raitakari OT, Järvelin MR, Würtz P, Kettunen J, Ala-Korpela M. Sex hormonebinding globulin associations with circulating lipids and metabolites and the risk for type 2 diabetes: observational and causal effect estimates. Int J Epidemiol 2015;44:623637. Epub 2015 Jun 6

70. Poyrazoglu S, Bas F, Darendeliler F. Metabolic syndrome in young people. Curr Opin Endocrinol Diabetes Obes 2014;21:56-63.

71. Agirbasli M, Ciliv G, Cakir S, Srinivasan S, Berenson GS, Ozme S. Body mass index and lipid levels in children from Ankara, Turkey versus Bogalusa, Louisiana. Prev Med 2005;41:843-845. Epub 2005 Sep 16

72. Wee BS, Poh BK, Bulgiba A, Ismail MN, Ruzita AT, Hills AP. Risk of metabolic syndrome among children living in metropolitan Kuala Lumpur: a case control study. BMC public health 2011;11:333.

73. Kolsgaard ML, Andersen LF, Tonstad S, Brunborg C, Wangensteen $\mathrm{T}$, Joner $\mathrm{G}$. Ethnic differences in metabolic syndrome among overweight and obese children and adolescents: the Oslo Adiposity Intervention Study. Acta Paediatr 2008;97:1557-1563. Epub 2008 Jul 24

74. Batey LS, Goff DC Jr, Tortolero SR, Nichaman MZ, Chan W, Chan FA, Grunbaum J, Hanis CL, Labarthe DR. Summary measures of the insulin resistance syndrome are adverse among Mexican-American versus non-Hispanic white children: the Corpus Christi Child Heart Study. Circulation 1997:96:4319-4325.

75. Galloway PJ, Donaldson MD, Wallace AM. Sex hormone binding globulin concentration as a prepubertal marker for hyperinsulinaemia in obesity. Arch Dis Child 2001;85:489491.

76. Agirbasli M, Agaoglu NB, Orak N, Caglioz H, Ocek T, Poci N, Salaj A, Maya S. Sex hormones and metabolic syndrome in children and adolescents. Metabolism 2009;58:1256-1262. Epub 2009 Jun 18

77. de Oya I, Schoppen S, Lasuncion MA, Lopez-Simon L, Riestra $P$, de Oya M, Garces C. Sex hormone-binding globulin levels and metabolic syndrome and its features in adolescents. Pediatric Diabetes 2010;11:188-194. Epub 2009 Jul 23

78. Agirbasli M, Agaoglu NB, Orak N, Caglioz H, Ocek T, Karabag T, Baykan OA. Sex hormones, insulin resistance and highdensity lipoprotein cholesterol levels in children. Horm Res Paediatr 2010;73:166-174. Epub 2010 Mar 3

79. Anjana RM, Lakshminarayanan S, Deepa M, Farooq S, Pradeepa R, Mohan V. Parental history of type 2 diabetes mellitus, metabolic syndrome, and cardiometabolic risk factors in Asian Indian adolescents. Metabolism 2009;58:344350.

80. Mathias RA, Deepa M, Deepa R, Wilson AF, Mohan V. Heritability of quantitative traits associated with type 2 diabetes mellitus in large multiplex families from South India. Metabolism 2009;58:1439-1445. Epub 2009 Jul 1

81. Lopez DS, Peskoe SB, Joshu CE, Dobs A, Feinleib M, Kanarek N, Nelson WG, Selvin E, Rohrmann S, Platz EA. Racial/ethnic differences in serum sex steroid hormone concentrations in US adolescent males. Cancer Causes Control 2013;24:817826. Epub 2013 Jan 25

82. Abdelrahaman $E$, Raghavan $S$, Baker $L$, Weinrich $M C$, Winters SJ. Racial difference in circulating sex hormonebinding globulin levels in prepubertal boys. Metabolism 2005;54:91-96. 
83. Hergenc G, Schulte H, Assmann G, von Eckardstein A. Associations of obesity markers, insulin, and sex hormones with HDL-cholesterol levels in Turkish and German individuals. Atherosclerosis 1999;145:147-156.

84. Ozhan H, Alemdar R, Caglar O, Ordu S, Kaya A, Albayrak S, Turker $Y$, Bulur S; MELEN Investigators. Performance of bioelectrical impedance analysis in the diagnosis of metabolic syndrome. J Investig Med 2012;60:587-591.

85. Fenske B, Kische $H$, Gross S, Wallaschofski H, Völzke H, Dörr M, Nauck M, Keevil BG, Brabant G, Haring R. Endogenous androgens and sex hormone-binding globulin in women and risk of metabolic syndrome and type 2 diabetes. J Clin Endocrinol Metab 2015:100:4595-4603. Epub 2015 Oct 7

86. Krishnasamy SS, Chang C, Wang C, Chandiramani R, Winters SJ. Sex hormone-binding globulin and the risk for metabolic syndrome in children of South Asian Indian origin. Endocr Pract 2012;18:668-675.

87. Agirbasli M, Eren F, Agirbasli D, White MJ, Williams SM. Multi-locus candidate gene analyses of lipid levels in a pediatric Turkish cohort: lessons learned on LPL, CETP, LIPC, ABCA1, and SHBG. OMICS 2013;17:636-645. Epub 2013 Aug 29

88. White MJ, Eren F, Agirbasli D, Williams SM, Agirbasli M. SHBG gene polymorphism (rs1799941) associates with metabolic syndrome in children and adolescents. PloS one 2015;10:0116915

89. Lewy VD, Danadian K, Witchel SF, Arslanian S. Early metabolic abnormalities in adolescent girls with polycystic ovarian syndrome. J Pediatr 2001;138:38-44.

90. Xita N, Tsatsoulis A, Chatzikyriakidou A, Georgiou I. Association of the (TAAAA)n repeat polymorphism in the sex hormone-binding globulin (SHBG) gene with polycystic ovary syndrome and relation to SHBG serum levels. J Clin Endocrinol Metab 2003;88:5976-5980.

91. Kosova G, Urbanek M. Genetics of the polycystic ovary syndrome. Mol Cell Endocrinol 2013;373:29-38. Epub 2012 Oct 16

92. Rosenfield RL. The diagnosis of polycystic ovary syndrome in adolescents. Pediatrics 2015;136:1154-1165.

93. Wabitsch $M$, Hauner $H$, Heinze E, Bockmann A, Benz R, Mayer $\mathrm{H}$, Teller $\mathrm{W}$. Body fat distribution and steroid hormone concentrations in obese adolescent girls before and after weight reduction. J Clin Endocrinol Metab 1995;80:34693475.

94. Reinehr T, de Sousa G, Roth CL, Andler W. Androgens before and after weight loss in obese children. J Clin Endocrinol Metab 2005;90:5588-5595. Epub 2005 Jul 12

95. Knudsen KL, Blank SK, Burt Solorzano C, Patrie JT, Chang RJ, Caprio S, Marshall JC, McCartney CR. Hyperandrogenemia in obese peripubertal girls: correlates and potential etiological determinants. Obesity (Silver Spring ) 2010;18:2118-2124. Epub 2010 Mar 25

96. Kent SC, Gnatuk CL, Kunselman AR, Demers LM, Lee PA, Legro RS. Hyperandrogenism and hyperinsulinism in children of women with polycystic ovary syndrome: a controlled study. J Clin Endocrinol Metab 2008;93:1662-1669. Epub 2008 Feb 12

97. Sir-Petermann T, Ladron de Guevara A, Codner E, Preisler J, Crisosto N, Echiburu B, Maliqueo M, Sanchez F, Perez-Bravo F, Cassorla F. Relationship between anti-Müllerian hormone $(\mathrm{AMH})$ and insulin levels during different tanner stages in daughters of women with polycystic ovary syndrome. Reprod Sci 2012;19:383-390. Epub 2012 Feb 16
98. Melo AS, Vieira CS, Barbieri MA, Rosa-E-Silva AC, Silva AA, Cardoso VC, Reis RM, Ferriani RA, Silva-de-Sá MF, Bettiol $\mathrm{H}$. High prevalence of polycystic ovary syndrome in women born small for gestational age. Human Reprod 2010;25:21242131. Epub 2010 Jun 23

99. Ibanez L, Lopez-Bermejo A, Suarez L, Marcos MV, Diaz M, de Zegher F. Visceral adiposity without overweight in children born small for gestational age. J Clin Endocrinol Metab 2008;93:2079-2083. Epub 2008 Mar 11

100. Ibanez L, Lopez-Bermejo A, Diaz M, Suarez L, de Zegher F. Low-birth weight children develop lower sex hormone binding globulin and higher dehydroepiandrosterone sulfate levels and aggravate their visceral adiposity and hypoadiponectinemia between six and eight years of age. $J$ Clin Endocrinol Metab 2009;94:3696-3699. Epub 2009 Sep 8

101. Byrne CD, Targher G. NAFLD: a multisystem disease. J Hepatol 2015;62(Suppl 1):47-64.

102. Vajro P, Lenta S, Socha P, Dhawan A, McKiernan P, Baumann $U$, Durmaz O, Lacaille F, McLin V, Nobili V. Diagnosis of nonalcoholic fatty liver disease in children and adolescents: position paper of the ESPGHAN Hepatology Committee. J pediatr Gastroenterol Nutr 2012;54:700-713.

103. Lee DH, Blomhoff $R$, Jacobs DR Jr. Is serum gamma glutamyltransferase a marker of oxidative stress? Free Radic Res 2004;38:535-539.

104. Shin JY, Kim SK, Lee MY, Kim HS, Ye BI, Shin YG, Baik SK, Chung $\mathrm{CH}$. Serum sex hormone-binding globulin levels are independently associated with nonalcoholic fatty liver disease in people with type 2 diabetes. Diabetes Res Clin Pract 2011;94:156-162. Epub 2011 Sep 8

105. Ma RC, Liu KH, Lam PM, Cheung LP, Tam WH, Ko GT, Chan $\mathrm{MH}$, Ho CS, Lam CW, Chu WC, Tong PC, So WY, Chan JC, Chow CC. Sonographic measurement of mesenteric fat predicts presence of fatty liver among subjects with polycystic ovary syndrome. J Clin Endocrinol Metab 2011;96:799-807. Epub 2010 Dec 29

106. Ayonrinde OT, Adams LA, Doherty DA, Mori TA, Beilin LJ, Oddy WH, Hickey $M$, Sloboda DM, Olynyk JK, Hart R. Adolescent females with NAFLD and PCOS have an adverse metabolic phenotype compared with other females and males. J Gastroenterol Hepatol 2015. Epub ahead of print

107. Gangale MF, Miele L, Lanzone A, Sagnella F, Martinez D, Tropea A, Moro F, Morciano A, Ciardulli A, Palla C, Pompili M, Cefalo C, Grieco A, Apa R. Long-term metformin treatment is able to reduce the prevalence of metabolic syndrome and its hepatic involvement in young hyperinsulinaemic overweight patients with polycystic ovarian syndrome. Clin Endocrinol 2011;75:520-527.

108. Wolfgram PM, Connor EL, Rehm JL, Eickhoff JC, Reeder $\mathrm{SB}$, Allen DB. Ethnic differences in the effects of hepatic fat deposition on insulin resistance in nonobese middle school girls. Obesity (Silver Spring) 2014;22:243-248. Epub 2013 Sep 17

109. Biro FM, Greenspan LC, Galvez MP, Pinney SM, Teitelbaum S, Windham GC, Deardorff J, Herrick RL, Succop PA, Hiatt RA, Kushi LH, Wolff MS. Onset of breast development in a longitudinal cohort. Pediatrics 2013;132:1019-1027. Epub 2013 Nov 4

110. Ball GD, Huang TT, Gower BA, Cruz ML, Shaibi GQ, Weigensberg MJ, Goran MI. Longitudinal changes in insulin sensitivity, insulin secretion, and beta-cell function during puberty. J Pediatr 2006;148:16-22.

111. Sorensen K, Aksglaede L, Munch-Andersen T, AachmannAndersen NJ, Petersen JH, Hilsted L, Helge JW, Juul A. Sex hormone-binding globulin levels predict insulin sensitivity, disposition index, and cardiovascular risk during puberty. Diabetes care 2009;32:909-914. Epub 2009 Feb 5 
Aydin B and Winters SJ.

Sex Hormone-Binding Globulin in Children and Adolescents

112. Sorensen K, Andersson AM, Skakkebaek NE, Juul A. Serum sex hormone-binding globulin levels in healthy children and girls with precocious puberty before and during gonadotropin-releasing hormone agonist treatment. J Clin Endocrinol Metab 2007;92:3189-3196. Epub 2007 May 22

113. He Q, Karlberg J. Bmi in childhood and its association with height gain, timing of puberty, and final height. Pediatric Res 2001;49:244-251

114. Sorensen K, Aksglaede L, Petersen JH, Juul A. Recent changes in pubertal timing in healthy Danish boys: associations with body mass index. J Clin Endocrinol Metab 2010;95:263-270. Epub 2009 Nov 19

115. Vandewalle $S$, Taes $Y$, Fiers $T$, Van Helvoirt $M$, Debode $P$, Herregods N, Ernst C, Van Caenegem E, Roggen I, Verhelle F, De Schepper J, Kaufman JM. Sex steroids in relation to sexual and skeletal maturation in obese male adolescents. J Clin Endocrinol Metab 2014;99:2977-2985. Epub 2014 May 5

116. Lee JM, Kaciroti N, Appugliese D, Corwyn RF, Bradley RH, Lumeng JC. Body mass index and timing of pubertal initiation in boys. Arch Pediatr Adolesc Med 2010;164:139-144.

117. Lee JM, Wasserman R, Kaciroti N, Gebremariam A, Steffes J, Dowshen S, Harris D, Serwint J, Abney D, Smitherman $L$, Reiter $E$, Herman-Giddens ME. Timing of Puberty in Overweight Versus Obese Boys. Pediatrics 2016 Jan 27. pii: peds. 2015-0164. [Epub ahead of print]
118. Vandewalle S, De Schepper J, Kaufman JM. Androgens and obesity in male adolescents. Curr Opin Endocrinol Diabetes Obes 2015;22:230-237.

119. Denburg MR, Silfen ME, Manibo AM, Chin D, Levine LS, Ferin M, McMahon DJ, Go C, Oberfield SE. Insulin sensitivity and the insulin-like growth factor system in prepubertal boys with premature adrenarche. J Clin Endocrinol Metab 2002;87:5604-5609.

120. Potau N, Ibanez L, Rique S, Sanchez-Ufarte C, de Zegher F. Pronounced adrenarche and precocious pubarche in boys. Horm Res 1999;51:238-241.

121. Hui SL, Dimeglio LA, Longcope C, Peacock M, McClintock $\mathrm{R}$, Perkins AJ, Johnston CC, Jr. Difference in bone mass between black and white American children: attributable to body build, sex hormone levels, or bone turnover? J Clin Endocrinol Metab 2003;88:642-649.

122. Danielson KK, Drum ML, Estrada CL, Lipton RB. Racial and ethnic differences in an estimated measure of insulin resistance among individuals with type 1 diabetes. Diabetes care 2010;33:614-619. Epub 2009 Dec 10

123. Hannon TS, Arslanian SA. Differences in stimulated androgen levels in black and white obese adolescent females. J Pediatr Adolesc Gynecol 2012;25:82-85. Epub 2011 Nov 16 